\title{
Flexural strengthening of timber beams by traditional and innovative techniques
}

Received (in revised form): 20th June, 2007

\begin{abstract}
Maria Rosa Valluzzi
graduated with a degree in Civil Engineering from the University of Padova (Italy) and a PhD on 'Design and preservation of structures' from the University of Trieste (Italy) and is currently a researcher on Restoration at the University of Padova. An assistant professor teaching graduate and post-graduate courses, she is also involved in several research projects concerning the strengthening and repair of masonry buildings and structures, and the preservation of the cultural heritage in seismic areas. She is the author and co-author of more than 150 publications, is a member of national and international committees for standardisation (UNI, RILEM), and was awarded the Robert L'Hermite medal by RILEM in 2005.
\end{abstract}

\section{Enrico Garbin}

graduated with a degree in Architectural Engineering from the University of Padova and is currently enrolled in a PhD course in 'Modelling conservation and control of materials and structures' at the University of Trento (Italy). He is the author and co-author of 30 papers and his research topics include the structural behaviour of historical masonry constructions and timber components, characterisations of new masonry systems, and numerical modelling.

\section{Claudio Modena}

is a full professor of Structural Engineering at the University of Padova and is Director of post-graduate courses and of the Laboratory of Materials Testing of the Department of Structural and Transportation Engineering. He is the author of over 300 publications and is a member of national and international scientific organisations and technical commissions for standardisation (UNI, ISO, RILEM, CEN, JCSS, EAEE, ICOMOS). He is interested in construction analysis and design with particular focus on historical and monumental masonry structures, strengthening/ retrofitting in seismic areas, monitoring, retrofitting of arch bridges, and safety evaluations, is an expert on restoration and conservation of historic masonry and monuments, and is responsible for several research projects and R\&D contracts with industry. He maintains a balance between academic and practical experience, combining research work and technical consulting to mutual benefit.

Correspondence: Maria Rosa Valluzzi, DAUR, University of Padova, Via Marzolo 9, Padova 35131, Italy; Tel/Fax: + 39049 8275576; E-mail:valluzzi@dic.unipd.it

\begin{abstract}
This work presents experimental analyses for validating various strengthening techniques applied to historic timber floors using traditional and/or innovative materials (FRP, fibre reinforced polymer). The traditional method proposed here consists of placing reinforcing planks above the existing floor beams and fixing them with 'dry' connections by means of wooden dowels. As an innovative technique, strengthening with wet lay-up carbon FRP laminates (CFRP) applied at the underside of the beams is examined, both as unique strengthening for floor beams and in combination with the above-mentioned traditional method on the composite structure. Results on the characterisation of the connections between materials ('dry' wooden dowels and FRP bond behaviour) and flexural tests on simple and mechanically jointed beams with or without CFRP strengthening are discussed. The main execution phases of the strengthening technique, and their limits and advantages, are also described.

Journal of Building Appraisal (2007) 3, 125-143. doi:10.1057/palgrave.jba.2950071
\end{abstract}

\section{Keywords:}

timber floor, flexural behaviour, dowels, CFRP, strengthening, repair 


\section{INTRODUCTION}

The main problems affecting the structural behaviour of historic timber floors are due to the lack of bending and in-plane stiffness and to the inadequate mechanical properties of the existing material. Several strengthening techniques have been developed in order to increase the bending stiffness and load-bearing capacity of existing timber floors, particularly in the case of simple frame floors made of rectangular load-bearing timbers (Tampone, 1996).

Among these, some are based on introducing strengthening elements like fibre reinforced polymer (FRP) strips or bars at the floor underside; others aim at creating a T-beam section, where the original timber behaves like a web, and a new element, placed at the floor upper side and connected to the existing beam, works as a flange. This element may be made of various types and materials, like the shear connection between the existing beam and the strengthening element (Parisi and Piazza, 2003). In particular, when the existing boarding is to be maintained, special shear and flexural fasteners must be used in order to reduce the possible loss of stiffness at the connection. For this purpose, steel beams coupled to the original beams (Tampone, 1996) or reinforced concrete slabs collaborating with the existing beams are usually used (Piazza et al., 2005).

In the last decade, an intervention technique, based on the use of wooden elements for both flange and dowels connecting the original beam, has been developed in order to preserve and strengthen existing wooden floors (Modena et al., 1997, 1998, 2004). Several experiments have validated this reinforcing system as highly compatible with the original floors, and led to the identification of the proper parameters to control for in situ applications (Modena et al., 2004), according to the basic principles of cautious repairs (Modena, 1997). In particular, the choice of type of dowels (steel or wood), their diameter, and possible connection at the interface between flange and web (with glue or resins at the interface, or in 'dry' conditions, ie, simply forcing them into pre-bored holes) is important (Modena et al., 2004). The technique is applied from the floor upper side (to which access is required) and only causes small increases in floor thickness and dead load. Traditional materials, the time-dependent behaviour of which is well known, and 'dry' assembly methods promote the durability, compatibility, reversibility, and/or recoverability of the intervention.

The contribution of FRP strips (Gentile et al., 2002; Borri et al., 2004) applied at the floor underside can increase beam structural performance, with or without specific strengthening at the upper side. Mechanical behaviour strongly depends on the local bond at the interface between wood and fibres subjected to various types of action (debonding, peeling), and may be particularly sensitive to the environmental conditions of the wood, mainly the relative humidity of the substrate. Italian standards recommend a limit of 10 per cent relative humidity to ensure proper adhesion of fibres to porous materials like masonry (CNR-DT200, 2004), and the use of polymer resins able to ensure durability, in cases of mechanical and dimensional variations in timber materials (CNR-DT201, 2005). In wood, relative humidity of the substrate of 12 per cent seems to be adequate to allow proper bond behaviour of glued elements (Piazza et al., 2005).

The behaviour of 'dry' wooden connections compared with steel dowels and glued wooden dowels (ascertained by push-out tests), the bonding behaviour between carbon FRP laminates (CFRP) and wood (pull-off and double-lap shear tests), and the bending behaviour of simple and T-beams, with or without CFRP strengthening, have been experimentally investigated. The results of experimental tests on compound beams have been analysed according to the theory provided by Eurocode 5 (2003). 


\section{STRENGTHENING TECHNIQUES}

\section{Timber flange connected by dowels to main beams}

The reinforcing technique consists of placing a new plank connected by means of dowels above each beam of the existing frame (Modena et al., 1997, 1998). To facilitate execution and to ensure compatibility with existing structures and materials, in the original conception of the intervention the dowels were made of hardwood and driven into the preferably 'dry'-planks, that is, without any material to improve adhesion inside the hole (Figure 1a). Moreover, with proper connection of main beams to load-bearing walls, and possible additional planks in the upper surface, the system can efficiently work even in seismic zones (Figure 1b) (Modena et al., 2004). A T-beam compound section, whose web (original beam) and flange (new plank) are made of wood, with deformable connections between the flange and web, is thus obtained. Web and flange are separated by the existing boarding, having a thickness of $2-2.5 \mathrm{~cm}$. Figure $1 \mathrm{c}$ shows the typical unequal spacing of the dowels along a beam in the prevalent shear zone, and Figure 1d
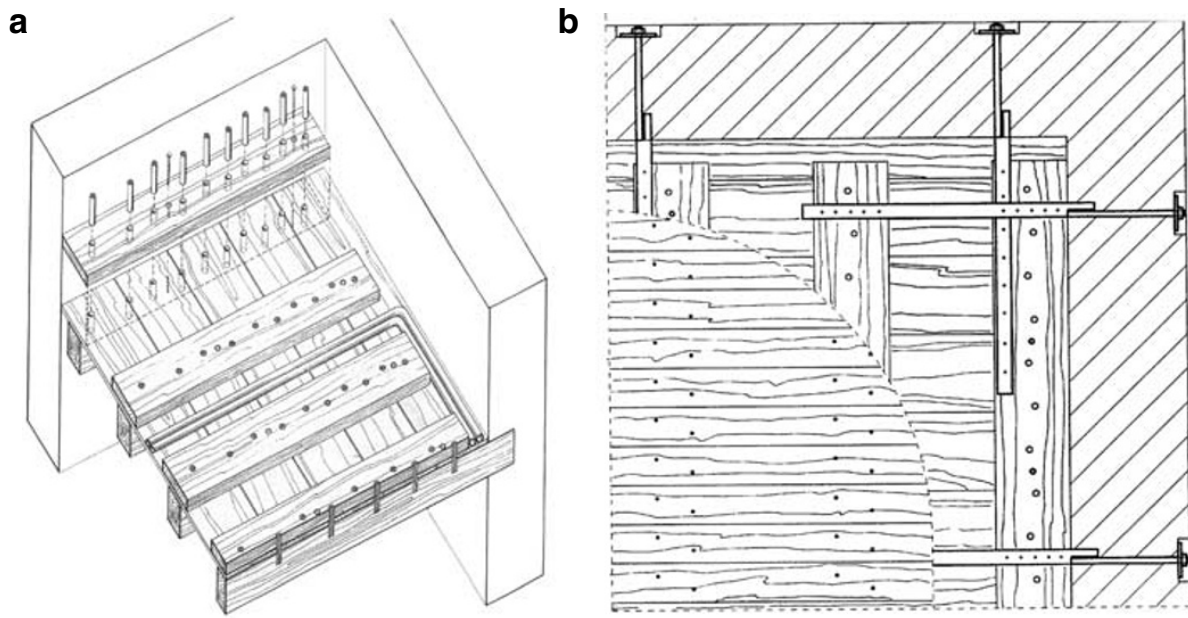

C

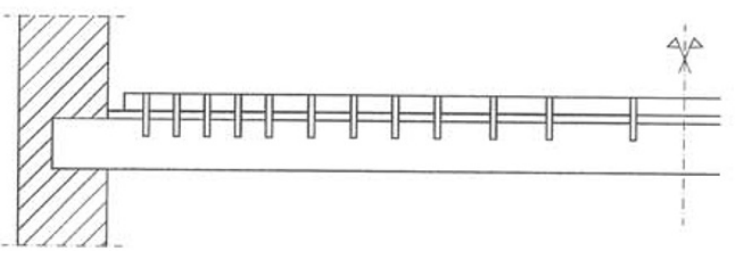

d
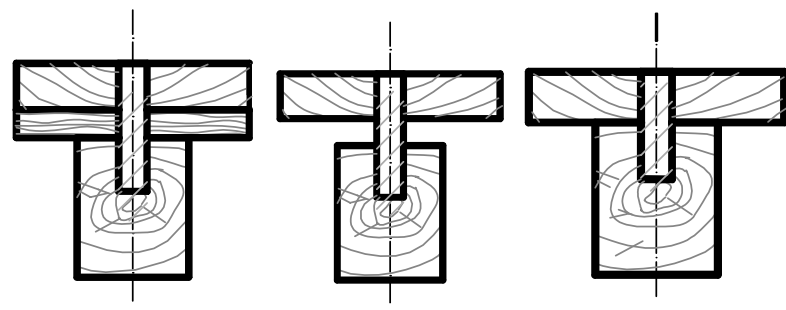

Figure I: Stiffening intervention with dry hardwood pins to connect planks and/or boardings to original timber floors $(\mathrm{a}, \mathrm{b})$ and detail of connection to walls (b); distribution of dowels along a main beam (c); and different working of connections depending on contribution of boarding (d): combined flexural and shear (left), bending (centre), pure shear (right) 
shows the different mechanical behaviour of compound sections with deformable connections. The operation is executed from the underside of the floor, thus preserving possible valuable floor surfaces and enables the instalment of systems (electrical, water, etc) without impairing the walls at their base (Figure 2).

The stiffening planks must be sawn before being placed on the boarding and their undersides levelled to allow perfect adhesion with the existing surface. The planks can be fixed to the existing boarding by means of screws to facilitate subsequent intervention phases and, when the floor beams are not propped, to provide adhesion between the straight planks and the permanently deflected floor beams. The screws can be placed every four to six dowels, in pre-drilled countersunk holes. The planks must be placed with the pith upward, in order to maintain the screws in tension even after wood shrinkage. Subsequently, the position where the dowels were inserted can be drawn into the plank by means of a template.

Dowel positions are staggered by about half a diameter from the longitudinal beam axis, in order to increase the resistance of the system to longitudinal splitting. The pre-bored holes are about $1 \mathrm{~mm}$ smaller than the dowel diameter. They are cleaned with
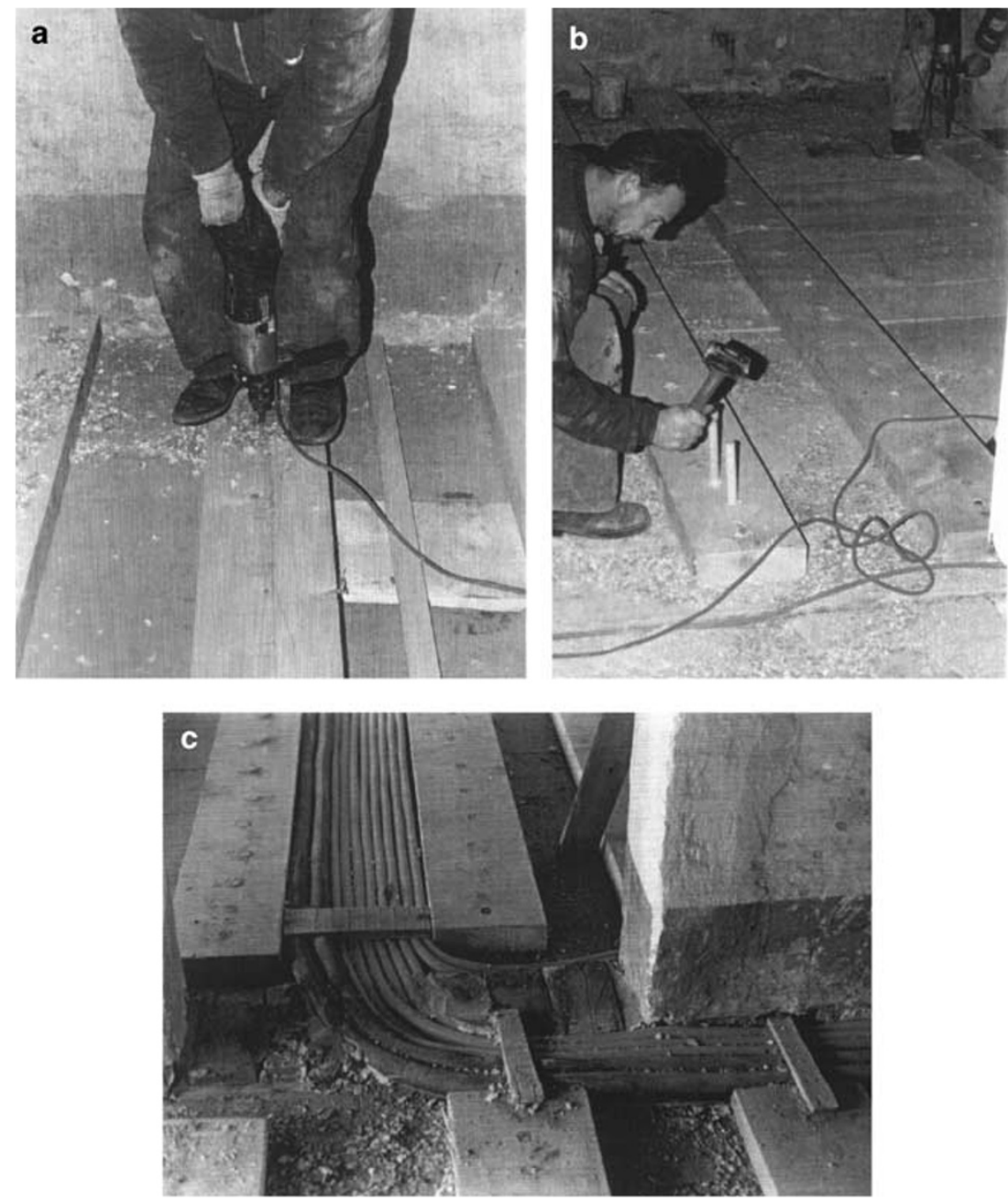

Figure 2: Execution phases: pre-boring (a), fixing of dowels on strengthening planks (b), and detail of technical installations placed between two planks (c) 
compressed air before forcing the dowels by hammering. Figure 2 shows some work phases in an historical building (Modena et al., 2004).

\section{Application of FRP at underside of main beams}

The innovative strengthening technique concerns gluing FRP strips to the floor underside and has already been proposed for simple rectangular beams (Gentile et al., 2002; Borri et al., 2004). The bond at the interface and the strengthening configuration are the main aspects that influence the mechanical behaviour of the reinforced beam.

A wet lay-up system is applied on the experimental beams, according to the manufacturer's recommendations. It consists of applying thin layers of adhesive (primer, epoxy resin) to guarantee proper homogeneity of the support to the fibres (Figure 3 ) as done for concrete substrates, although recent research (Cruz et al., 2004) demonstrates good gluing without application of primer. As regards possible applications to historical structures, it is worth noting that an FRP application is not compatible with preservation principles, for instance, in the case of decorated intrados.

\section{Combined technique}

The combination of the two above-mentioned techniques, that is, the dry connection with a timber flange at the upper side and a sheet of CFRP at the underside, may be considered for strengthening and/or repair of an earlier intervention applying one of them. This may be due to specific damage (failure of dowels, peeling of fibres) or, as an example, the influence of
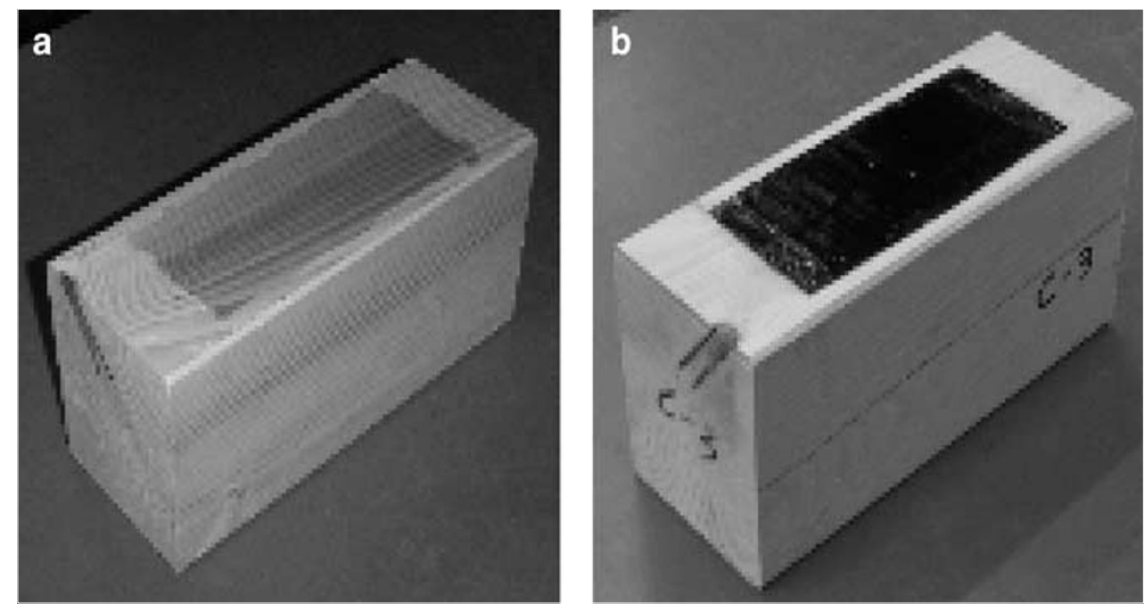

Figure 3: Application phases of primer (a) for preliminary preparation of surface and subsequent positioning of a layer of CFRP between adhesive resin (b)
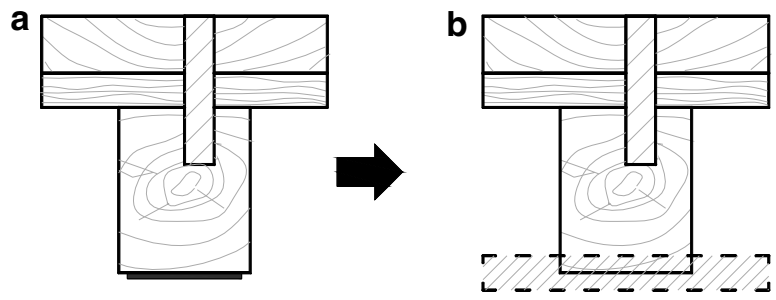

Figure 4: Compound section resulting from application of two techniques (FRP layer at bottom) (a) and equivalent timber I-section after homogenisation (b) 

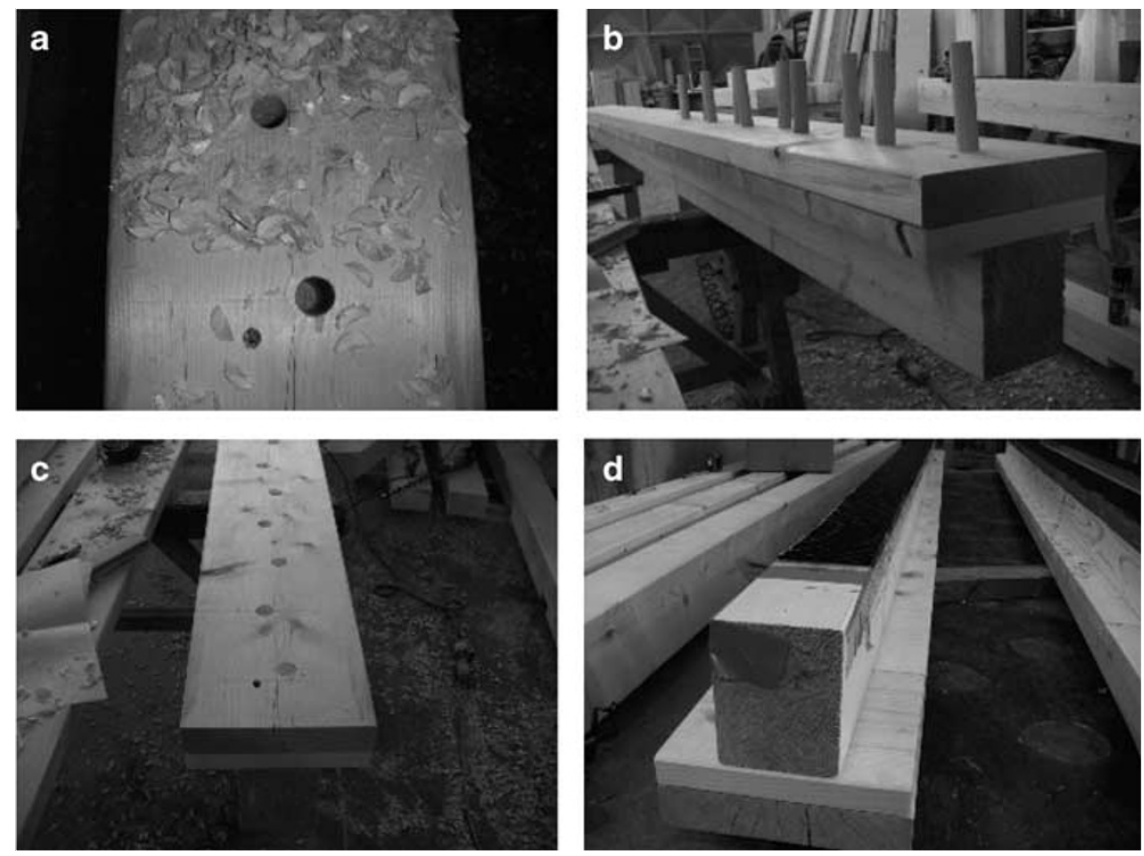

Figure 5: Experimental execution phases of combination of two techniques: preliminary drilling of extrados of main beam (a), positioning of hardwood dowels (b), complete strengthening on the upper side (c), and final application of CFRP at the underside (d)

humidity, which can reduce bond efficiency and lead to brittle collapse. The combined system also allowed checking the appearance of new modes of failure and their possible interference. From a structural point of view, the new element behaves like an I-section, where the flanges are the new plank and the homogenised FRP strip (Figure 4). Figure 5 shows an example of preparation of an experimental sample to be tested in the laboratory.

\section{EXPERIMENTAL PROGRAMME AND TEST SET-UP}

A comprehensive experimental campaign, aimed at characterising the mechanical behaviour and studying the parameters needed for proper design of upgrading existing wooden floors with the proposed techniques, was carried out at the Laboratory for Structural Materials Testing of the University of Padova. Several experimental phases were carried out, first on characterising the extrados technique (1997-2004), and then of FRP strengthening and combined interventions (2005).

As regards strengthening with timber flanges and dowels, various types of connections (wood or steel dowels, screws or rivets, or a combination of them), of various lengths (from 110 to $180 \mathrm{~mm}$ ) or diameters (from 20 to $29 \mathrm{~mm}$ for wooden connections, and from 12 to 20 for steel ones), with or without the use of different types of glue (vinyl, phenol, melamine, resorcinol, or epoxy resins) were tested (Modena et al., 1997, 2004).

Characterisation was performed by push-out tests on the various connection types, under loading control and according to the UNI-EN 26891 (1991) standard (Figure 6a), which allows evaluation of the main parameters characterising the connection (Figure 6b). The simplified design method for mechanically jointed beams with deformable fasteners was developed by Möhler (1956) and is assumed by Eurocode 5 (2003). The compound section is characterised by effective bending stiffness $(E J)_{e f f}$, as in the equations of Figure $6 \mathrm{c}$, 
where subscripts 1 and 2 refer to the stiffening plank and the existing beam, respectively, $d$ is the distance between the barycentres of plank and beam, $\gamma(0 \leqslant \gamma \leqslant 1$, where 0 and 1 refer to infinitely deformable and rigid connections, respectively) is the coefficient of efficiency of the connection, $l$ is the beam length, $s_{i}$ is the dowel spacing, and $K_{i}$ is the value of the instantaneous slip modulus. This last parameter is conventionally estimated for the serviceability limit state $\left(K_{s e r}\right)$ and ultimate limit state $\left(K_{u}\right)$ from the experimental load-displacement $(F-v)$ curve obtained by push-out tests (UNI-EN 26891, 1991) (Figure $6 \mathrm{a}$ and b). In particular, according to Eurocode 5 (2003), the slip modulus of a connection for ultimate limit state $K_{u}$ should be taken as $K_{u}=2 / 3 K_{s e r}$, where $K_{s e r}$ corresponds to the parameter $K_{s}$ defined in UNI-EN 26891 (1991).

Connections that showed the best behaviour were also tested in beams under flexure, according to the UNI-EN 380 (1994) standard. The beams were all made of spruce timber, with beech dowels and screws spaced at five diameters, according to the requirements of Eurocode 5 (2003) (Figure 7). The moisture content of the specimens was
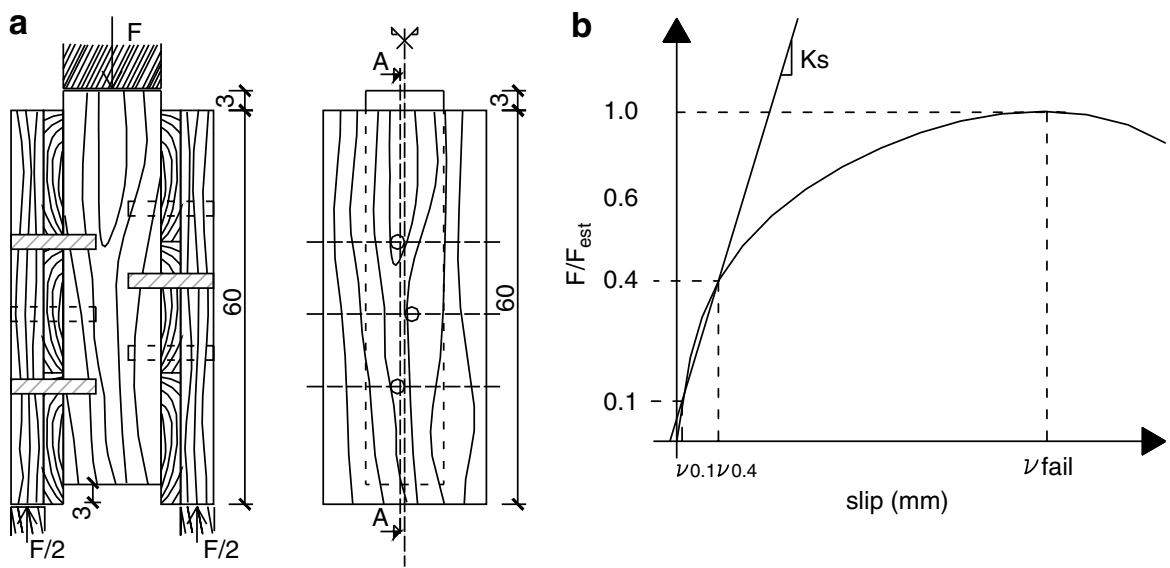

$$
\begin{aligned}
& (E J)_{0}=E_{1} J_{1}+E_{2} J_{2} \\
& (E A)_{S}=E_{1} A_{1}+E_{2} \mathrm{~A}_{2} \\
& (E A)_{P}=E_{1} A_{1} \cdot E_{2} A_{2} \\
& (E J)_{e f f}=(E J)_{0}+\gamma \frac{(E A)_{P}}{(E A)_{S}} \cdot d^{2} \\
& \gamma=\left(1+\pi^{2} \cdot \frac{(E A)_{P}}{(E A)_{S}} \cdot \frac{s_{i}}{K_{i} \cdot I^{2}}\right)^{-1}
\end{aligned}
$$

Figure 6: Push-out tests on compound sections: samples (a), typical experimental curve (b), parameters for definition of slip moduli $K_{i}$ and (c) characterising stiffness of connection

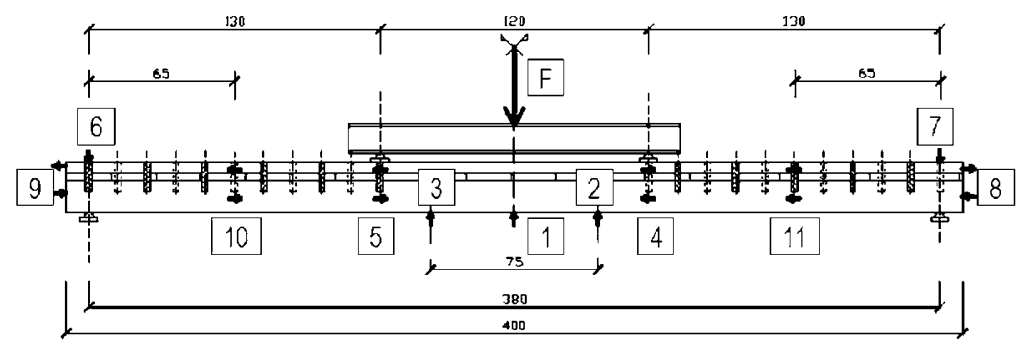

Figure 7: Geometry and bending test set-up for T-beams, showing position of transducers 
measured according to UNI 9091 (1987) after their construction and before carrying out tests. The reference value in compound beams before test was around 12 per cent; however, it was observed that small differences in moisture content did not cause any space at the dowel-hole interface.

The subsequent phase of the experiment was aimed at evaluating the structural behaviour of the FRP strengthening technique applied to wooden beams.

Characterisation of the bond behaviour of CFRP laminates and the flexural behaviour of FRP-strengthened simple and compound beams was performed. Bonding was studied by pull-off tests, according to ASTM C1583 (2004) (Figure 8), and double-lap shear

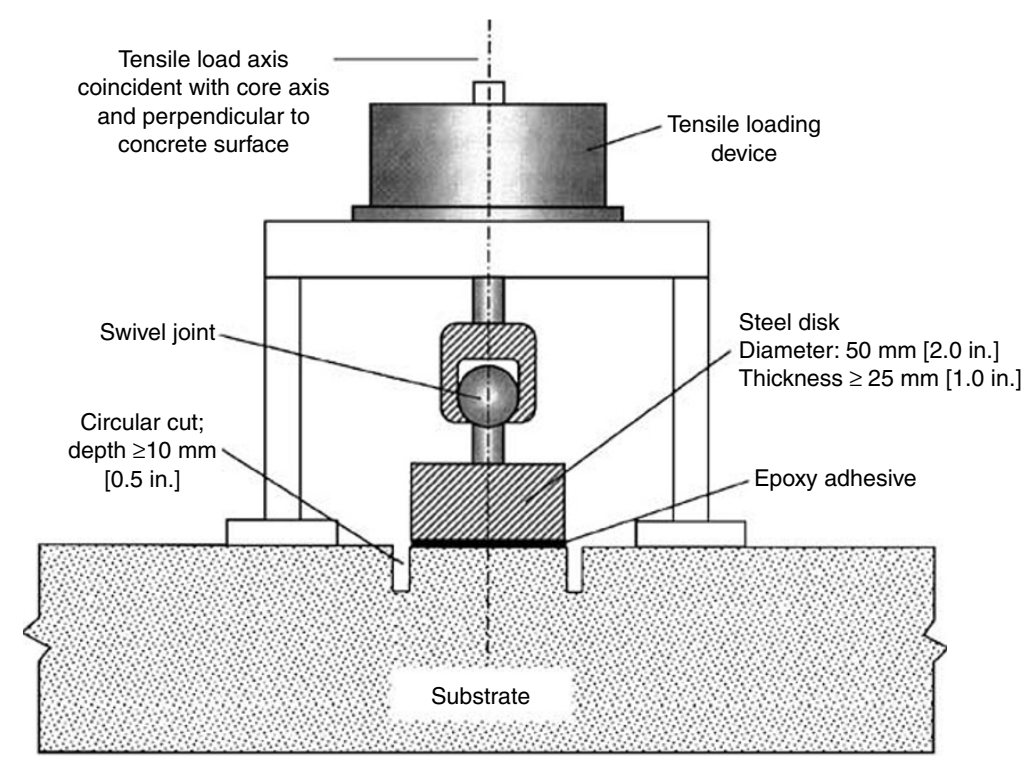

Figure 8: Pull-off test set-up according to ASTM CI583 (2004)
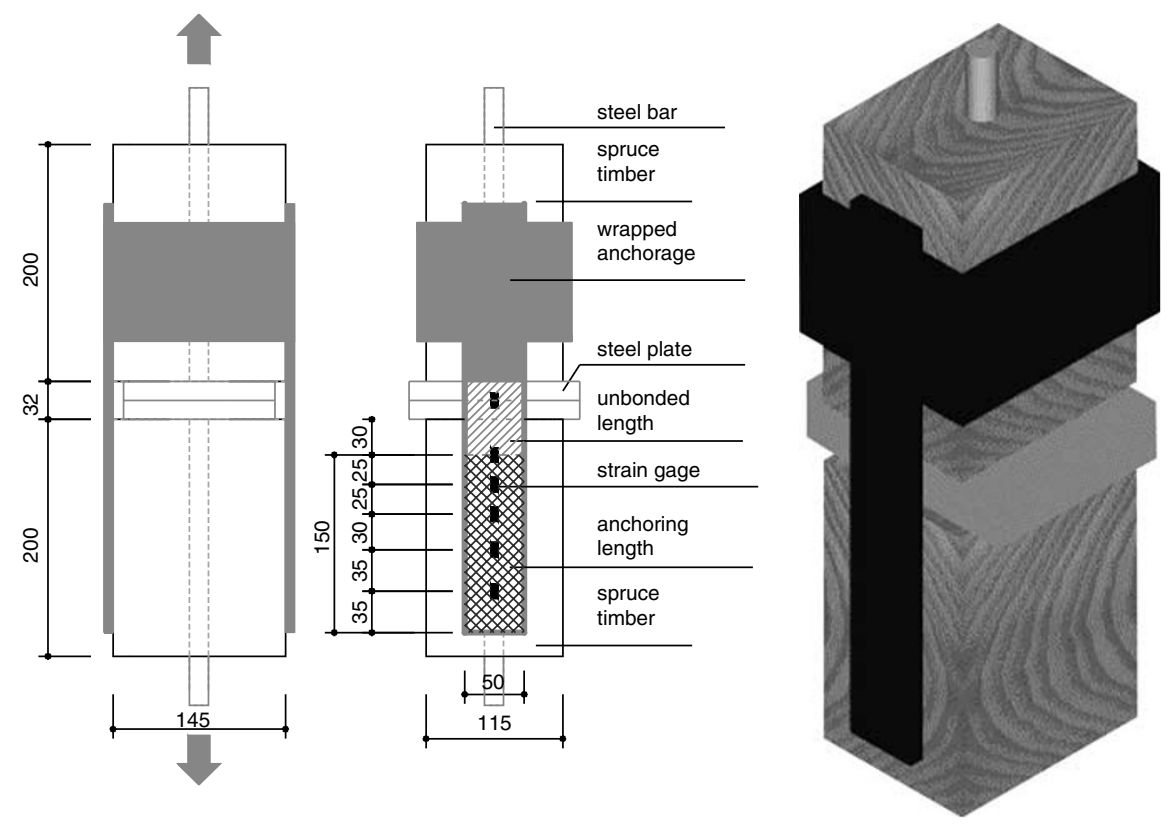

Figure 9: Double-lap shear test set-up (dimensions in $\mathrm{mm}$ ) 
testing of CFRP strips (Figure 9) (see also Aiello and Sciolti, 2005; Piazza et al., 2005). All specimens were made of spruce timber, and bending tests were carried out according to UNI-EN 380 (1994) and UNI-EN 480 (1997) (see Figure 7). Moisture content was measured according to UNI 9091 (1987) after beam construction (12 per cent) and before carrying out tests (up to 22 per cent). This difference in moisture content, probably accidentally due to transportation, was expected to influence the mechanical properties of the beams, as indicated in the relevant literature (Giordano, 1999; Piazza et al., 2005). The same four-point test illustrated in Figure 7 was adopted for beams strengthened with FRP sheets.

\section{TEST RESULTS OF LOCAL BEHAVIOUR}

\section{Timber connection with dowels}

In the first experimental phase (1997-2001), push-out tests showed that the best behaviour of the compound section was obtained by any intermediate boarding between original beam and reinforcing plank (Modena et al., 1997). When an empty space was left instead of the boarding, failure turned into combined shear-flexural collapse, with lower values of slip modulus and coefficient of efficiency (Table 1, Figure 10).

Table I: Results of push-out tests:Average values (three tests for each condition) obtained during various experimental campaigns

\begin{tabular}{|c|c|c|c|c|c|c|c|c|c|}
\hline \multirow{2}{*}{\multicolumn{3}{|c|}{$\begin{array}{l}\text { Sample: name, fastener material, and } \\
\text { type of connection }\end{array}$}} & \multirow{2}{*}{$\frac{\emptyset}{(\mathrm{mm})}$} & \multirow{2}{*}{$\begin{array}{l}\text { Length } \\
(\mathrm{mm})\end{array}$} & \multirow{2}{*}{$\begin{array}{l}F_{\max } \\
(\mathrm{N})\end{array}$} & \multirow{2}{*}{$\begin{array}{l}F_{\text {est }} \\
(\mathrm{N})\end{array}$} & \multirow{2}{*}{$\frac{v_{\mathrm{i}, \bmod }}{(\mathrm{mm})}$} & \multirow{2}{*}{$\begin{array}{l}v_{\text {fail }} \\
(\mathrm{mm})\end{array}$} & \multirow{2}{*}{$\begin{array}{l}\mathrm{K}_{\mathrm{s}} \\
(\mathrm{N} / \mathrm{mm})\end{array}$} \\
\hline & & & & & & & & & \\
\hline \multicolumn{10}{|c|}{ First experimental phase (I997-200I) } \\
\hline Sc20 & Wood & Vinyl resin & 20 & 130 & 8,612 & 8,326 & 0.62 & 11.91 & 5,721 \\
\hline Srm20 & Wood & Phenol resin & 20 & 130 & 8,561 & 8,243 & 0.77 & 7.21 & 4,400 \\
\hline Sn20 & Wood & Resorcin resin & 20 & 130 & 9,245 & 9,667 & 1.16 & 15.00 & 3,336 \\
\hline Scv20V & Wood & Vinyl+screws & 20 & 130 & 10,894 & 10,895 & 0.65 & 10.04 & 6,757 \\
\hline S20 & Wood & Dry & 20 & 130 & 6,189 & 6,070 & 2.40 & 14.63 & I,033 \\
\hline S2OV & Wood & Dry+screws & 20 & 130 & 9,042 & 8,542 & 0.84 & 15.00 & 4,068 \\
\hline St20* & Wood & Dry & 20 & 110 & 7,325 & 7,438 & 0.87 & 10.96 & 3,436 \\
\hline Sct20V* & Wood & Vinyl+screws & 20 & 110 & 15,783 & 15,292 & 0.65 & 10.04 & 8,011 \\
\hline Scv20** & Wood & Vinyl resin & 20 & 130 & 4,192 & 4,236 & 0.97 & 10.59 & I,866 \\
\hline Sv20** & Wood & Dry & 20 & 130 & 4,725 & 3,772 & 1.01 & 11.01 & I,495 \\
\hline Sc22 & Wood & Vinyl resin & 22 & 130 & 9,129 & 9,571 & 0.99 & 10.13 & 3,973 \\
\hline S22 & Wood & Dry & 22 & 130 & 6,067 & 6,625 & 3.06 & 15.00 & 867 \\
\hline ScM22 & Wood & Vinyl resin & 22 & 185 & 6,800 & 6,875 & 1.07 & 8.50 & 2,608 \\
\hline Sc26 & Wood & Vinyl resin & 25.4 & 130 & 9,472 & 9,535 & 0.85 & 14.15 & 4,933 \\
\hline S26 & Wood & Dry & 25.4 & 130 & 8,633 & 8,358 & 3.99 & 15.00 & 837 \\
\hline $\mathrm{Bc} 26$ & Wood & Vinyl resin & 25.4 & 110 & 8,263 & 7,925 & 0.74 & 15.00 & $4,3 \mid 3$ \\
\hline B26 & Wood & Dry & 25.4 & 110 & 7,635 & 7,528 & 1.73 & 15.00 & $\mathrm{I}, 788$ \\
\hline B26V & Wood & Dry+screws & 25.4 & 110 & 8,415 & 8,688 & 2.16 & 15.00 & $1,6 \mid 4$ \\
\hline $\mathrm{Bc} 26 \mathrm{~V}$ & Wood & Vinyl+screws & 25.4 & 110 & 8,843 & 8,731 & 0.79 & 15.00 & 4,404 \\
\hline $\mathrm{Sa} 20$ & Steel & Dry & 20 & 130 & 8,331 & 7,868 & 2.46 & 15.00 & I,332 \\
\hline Prel4 & Steel & Epoxy resin & 14 & 180 & 12,374 & 13,859 & 0.72 & 15.00 & 7,785 \\
\hline \multicolumn{10}{|c|}{ Second experimental phase $(200 I-2004)$} \\
\hline L20 & Wood & Dry & 20 & 130 & 5,606 & 5,994 & 1.92 & 10.07 & 1,270 \\
\hline L23 & Wood & Dry & 23 & 130 & 8,381 & 7,972 & 2.62 & 13.82 & 1,220 \\
\hline L26 & Wood & Dry & 26 & 130 & 9,979 & 9,278 & 1.59 & 14.86 & 2,337 \\
\hline L29 & Wood & Dry & 29 & 130 & 10,207 & 9,833 & 2.46 & $|4.6|$ & 1,600 \\
\hline $\mathrm{A} 12$ & Steel & Dry & 12 & 130 & 6,213 & 5,971 & 3.15 & 15.00 & 759 \\
\hline Al6 & Steel & Dry & 16 & 130 & 7,456 & 7,519 & 2.88 & 15.00 & 1,065 \\
\hline $\mathrm{A} 20$ & Steel & Dry & 20 & 130 & 9,310 & 9,358 & 3.86 & 15.00 & 999 \\
\hline
\end{tabular}

Notes: * tested without boarding in pure shear (adhesion); $* *$ tested without boarding, leaving empty space; $F_{\max }:$ maximum load at failure; $F_{\text {est }}$ : maximum estimated load; $v_{i, \text { mod }}$ : modified initial slip, equal to $4 / 3$ of difference between slip at $40 \%$ $\left(v_{0,4}\right)$ and $10 \%\left(v_{0,1}\right)$ of maximum estimated load $\left(F_{\text {est }}\right)$; $v_{\text {fail }}$ slip at failure according to UNI-EN 2689I (199I); slip modulus: $K_{s}=0.4 F_{\text {est }} / v_{i, \text { mod }}$, parameters required by current version of Eurocode 5 (2003) 
Glued dowels, particularly when vinyl resins were used, showed better results than dry dowels (Figure 10). Screws improved the behaviour at small displacements (higher initial slip modulus), but their contribution was lost at displacements exceeding $10 \mathrm{~mm}$. The best results in terms of connection efficiency were obtained with glued steel dowels (Table 1, Figure 10), although they had a stronger tendency to dowel bearing (splitting).

The second experimental phase (2001-2004) focused on optimisation of the diameter of dry beech wood dowels. Despite the lower $K_{s}$ values obtained in the preliminary phase, for preservation purposes, due to their easier positioning and removability, dry connections combine advantages in execution and sufficient mechanical effectiveness compared with other fastening systems. The proper optimised diameter was sought among 20,23,26, and $29 \mathrm{~mm}$ on beech wood dowels (L) $130 \mathrm{~mm}$ long. Comparisons were carried out with low-diameter $(12,16$, $20 \mathrm{~mm}$ ) smooth stainless-steel dowels (A).

The failure mode of the various beech wood connections is shown in Figure 11. It was characterised by combined shear-flexural behaviour, where small-diameter dowels failed in bending, whereas larger-diameter ones behaved mainly in shear. The best results were obtained for specimen L26 (dowels of $26 \mathrm{~mm}$ diameter) as seen in Table 1

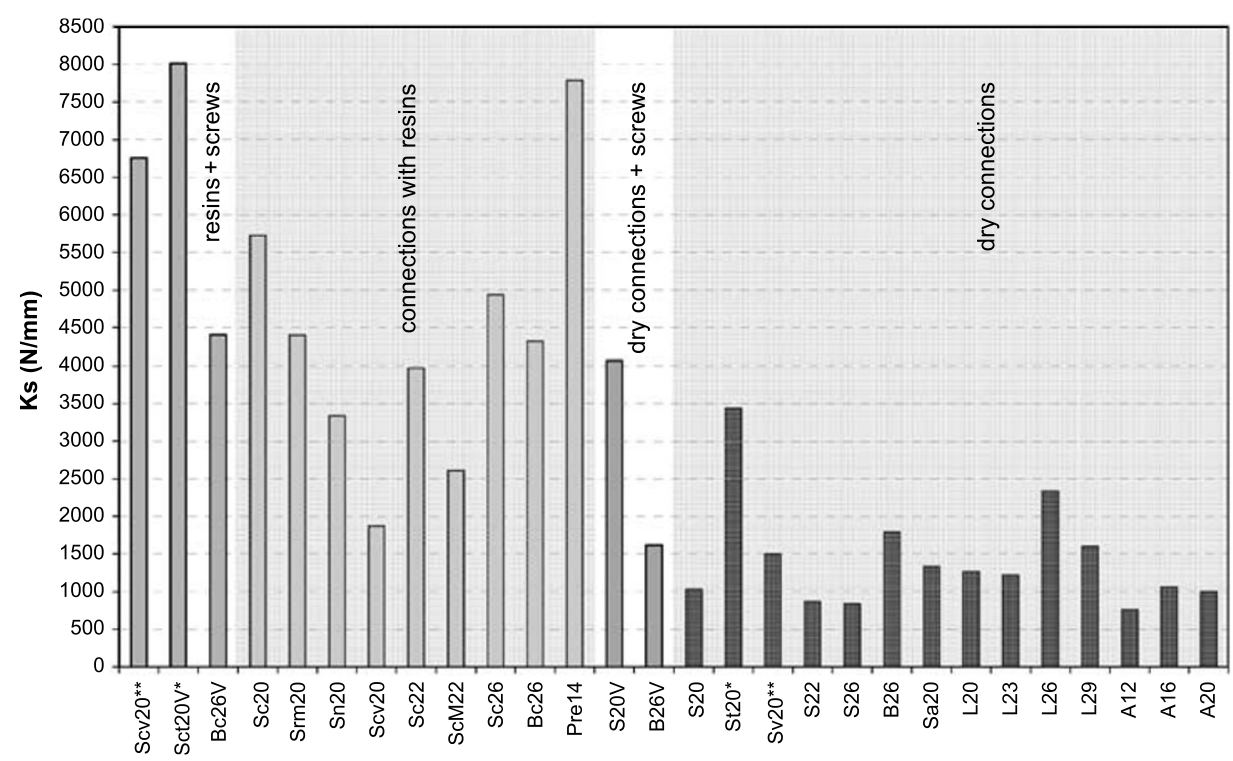

Figure 10: Comparison of various types of dowel connection. In dry connections, best results were obtained with beech dowel L26, since dowel St20 was tested without boarding in pure shear
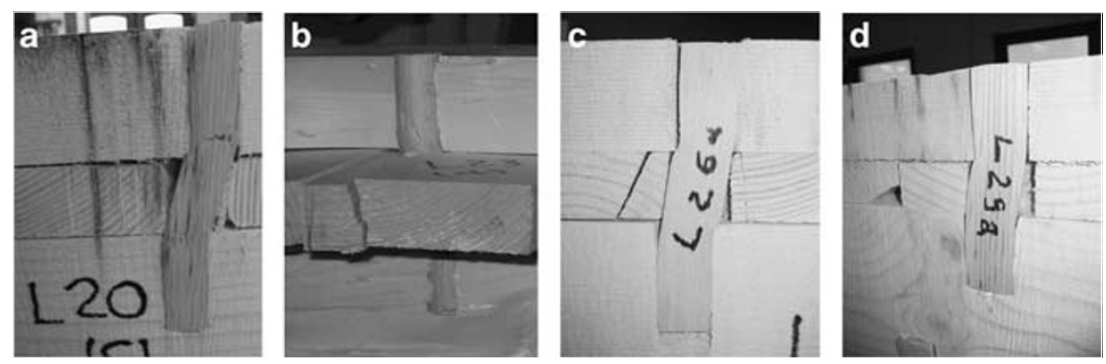

Figure I I: Combined shear-flexural failure of beech wood fasteners: L20 (a), L23 (b), L26 (c), and L29 (d) 

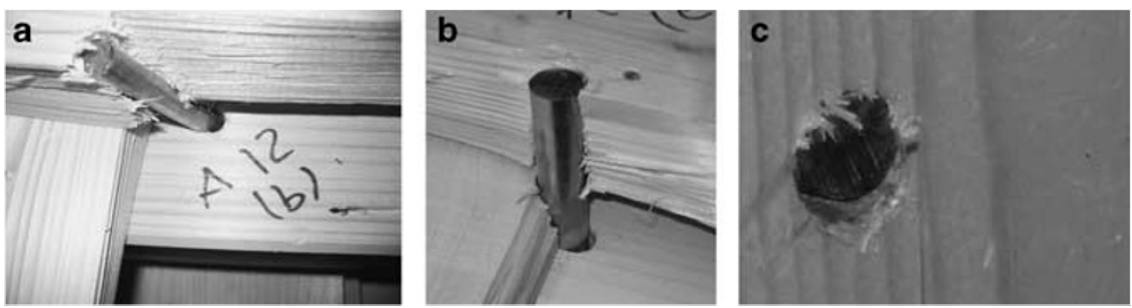

Figure 12: Prevalent splitting failure of hole for stainless-steel fasteners: AI2 (a), AI6 (b), and A20 (c)

Table 2: CFRP properties

\begin{tabular}{lll}
\hline Ultimate tensile stress & $(\mathrm{MPa})$ & 3550 \\
Elastic modulus & $(\mathrm{MPa})$ & 230,000 \\
Ultimate tensile strain & $(\%)$ & 1.5 \\
Nominal thickness & $(\mathrm{mm})$ & 0.165 \\
Coefficient of expansion & $\left(K^{-1}\right)$ & $10^{-7}$ \\
\hline
\end{tabular}

Table 3: Results of pull-off tests

\begin{tabular}{lllll}
\hline Specimen label & $\boldsymbol{P}_{\mathrm{u}}$ & $\begin{array}{l}\text { Tensile stress } \\
\text { orthogonal to grain }\end{array}$ & $\begin{array}{l}\text { Relative } \\
\text { humidity }\end{array}$ & $\begin{array}{l}\text { Failure mode } \\
\text { S= substrate } \\
\text { FM = fiber-matrix }\end{array}$ \\
\cline { 2 - 4 } & $\mathbf{( N )}$ & $\mathbf{( M P a )}$ & $\mathbf{( \% )}$ & \\
\hline $\mathrm{PO} / \mathrm{Cl}$ & 2,630 & 2.05 & 12 & $\mathrm{FM}$ \\
$\mathrm{PO} / \mathrm{C2}$ & 1,920 & 1.50 & 13 & $\mathrm{~F}$ \\
$\mathrm{PO} / \mathrm{C} 3$ & 1,840 & 1.44 & 13 & $\mathrm{~S}$ \\
$\mathrm{PO} / \mathrm{C} 4$ & 2,420 & 1.89 & 12 & $\mathrm{~S}$ \\
$\mathrm{PO} / \mathrm{C5}$ & 2,310 & 1.80 & 12 & \\
$\mathrm{PO} / \mathrm{C6}$ & 2,160 & 1.68 & 12 & \\
& & & 12.33 & \\
Average value & 2,213 & 1.73 & 0.52 & \\
Standard deviation & 301.3 & 0.23 & &
\end{tabular}

and Figure 10. Its maximum load at failure, $F_{\max }$, was lower than in specimens L29, but the slip moduli had the highest values, leading to a stiffer and more efficient connection. On average, connections made with dry beech wood dowels showed better behaviour than those made with steel dowels. The difference was due to the different failure modes (see Figures 11 and 12): wooden dowels failed in a combined shear-flexural state, with slight splitting of the hole for the larger diameters, whereas connections made with steel dowels failed, due to the bearing of the hole, before any deformation of the dowels could occur.

\section{CFRP-timber bond behaviour}

Before the application of CFRP to the simple and compound beams, the bond behaviour of the fibre laminate on spruce timber was evaluated, by pull-off and double-lap shear tests (Figures 8 and 9). The mechanical properties of CFRP materials are listed in Table 2.

The pull-off tests were performed by gluing steel cylinders $(40 \mathrm{~mm}$ in diameter) to the specimens with epoxy resin. After curing, six specimens were tested monotonically until failure. Spruce timber had relative humidity of 12 per cent. The average ultimate load $\left(P_{u}\right)$ was $2210 \mathrm{~N}$, and the average tensile stress orthogonal to the grain was $1.73 \mathrm{MPa}$ (Table 3). This value is in good agreement with the relevant literature (eg, Giordano, 1999), which suggests $1.68 \mathrm{MPa}$ as the ultimate value for tensile stress measured 


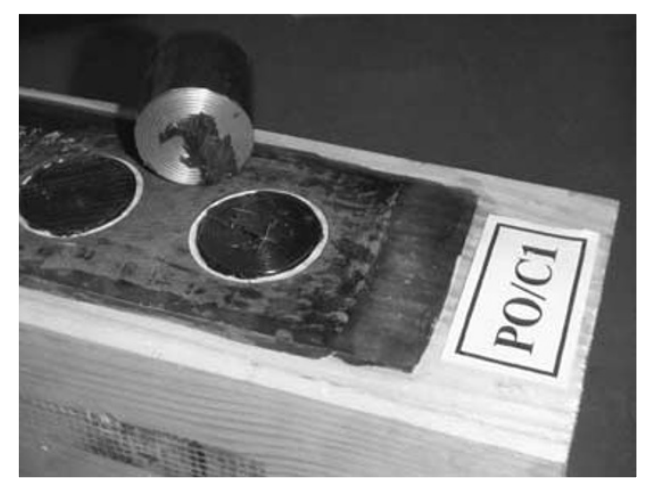

Figure 13: Pull-off test, failure surface inside fibre-matrix

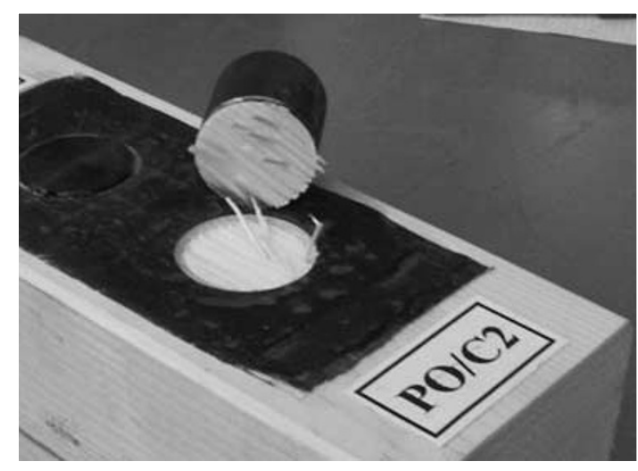

Figure 14: Pull-off test, failure surface inside wooden substrate

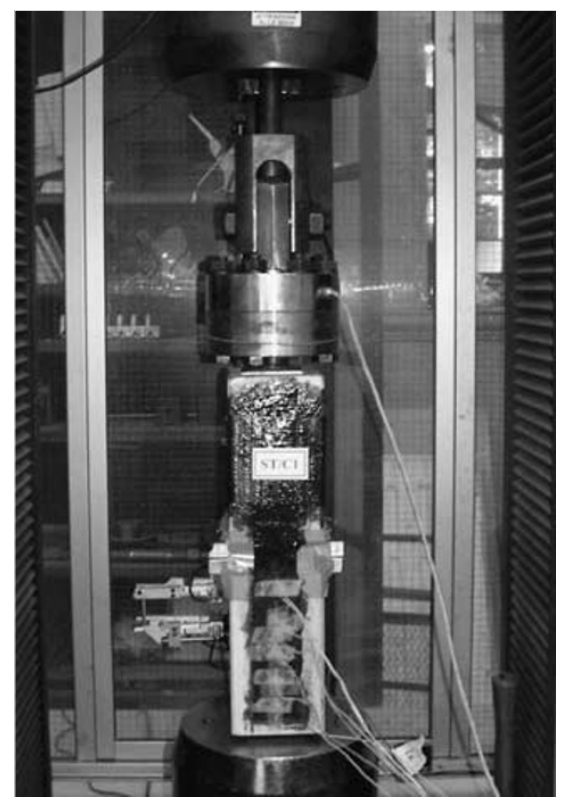

Figure 15: Double-lap shear test 
Table 4: Results of double-lap shear tests

\begin{tabular}{|c|c|c|c|}
\hline Specimen label & $\begin{array}{l}P_{\mathrm{u}}(\mathrm{N}) \text { ultimate load on } \\
2 \text { CFRP sheets }\end{array}$ & $\begin{array}{l}\sigma_{\mathrm{u}}(\mathrm{MPa}) \text { average tensile } \\
\text { stress on } 1 \text { CFRP sheet }\end{array}$ & $\begin{array}{l}\tau_{\text {average }}(\mathrm{MPa}) \text { average bond } \\
\text { stress over anchoring length } \\
\text { of } 150 \mathrm{~mm}\end{array}$ \\
\hline ST-CI & 18,788 & 1,139 & 1.25 \\
\hline ST-C2 & 19,177 & 1,162 & 1.28 \\
\hline ST-C3 & 24,404 & 1,479 & 1.63 \\
\hline ST-C4 & 22,532 & 1,366 & 1.50 \\
\hline ST-C5 & 20,289 & 1,230 & 1.35 \\
\hline ST-C6 & 25,516 & 1,546 & 1.70 \\
\hline Average value & 21,783 & $\mathrm{I}, 320$ & 1.45 \\
\hline Standard deviation & 2,805 & 170 & 0.19 \\
\hline
\end{tabular}
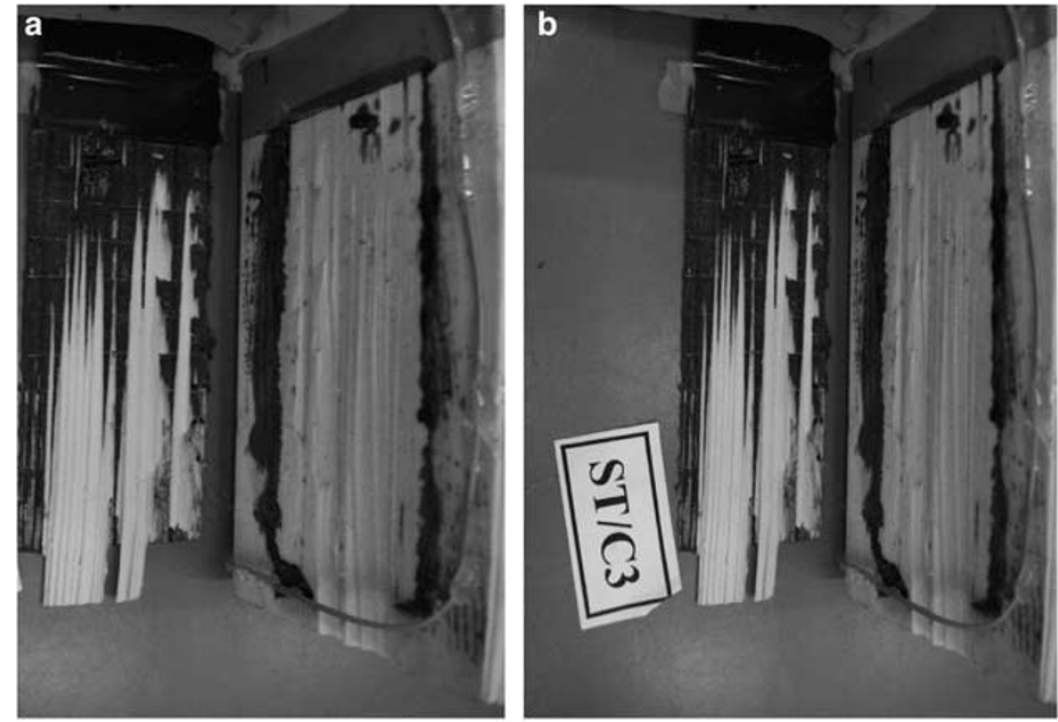

Figure 16: Bonding failure inside wooden substrate: specimens ST/CI (a) and ST/C3 (b)

orthogonally to grain for spruce timber. Failure surfaces were mainly located inside the substrate (Figures 13 and 14), revealing good bond behaviour between CFRP and spruce timber.

For double-lap shear tests, the instrumentation illustrated in Figure 9 was set up (Figure 15); six tests were executed in displacement control. Strain gauges were applied along the CFRP anchoring zone $(150 \mathrm{~mm})$ to calculate the effective anchoring length due to the development of bonding shear stresses. As in the previous case, spruce timber had a relative humidity of 12 per cent. CFRP ultimate loads and tensile stresses were experimentally determined (Table 4). A first evaluation of average bond stress over the anchoring length gave a value of $1.45 \mathrm{MPa}$ (Table 4). Failure surfaces involved the wooden substrate, again confirming the good bond behaviour between CFRP and spruce timber (Figure 16).

It is worth noting that local bond shear stress may be several times higher than average stress over the anchoring length. This is due to the nonlinear distribution of local shear stresses, as shown in Figure 17, in which the highest value (7 MPa) is comparable with the ultimate shear stress parallel to grain $(9 \mathrm{MPa})$, as noted in the relevant literature (eg, Giordano, 1999) for spruce timber. 


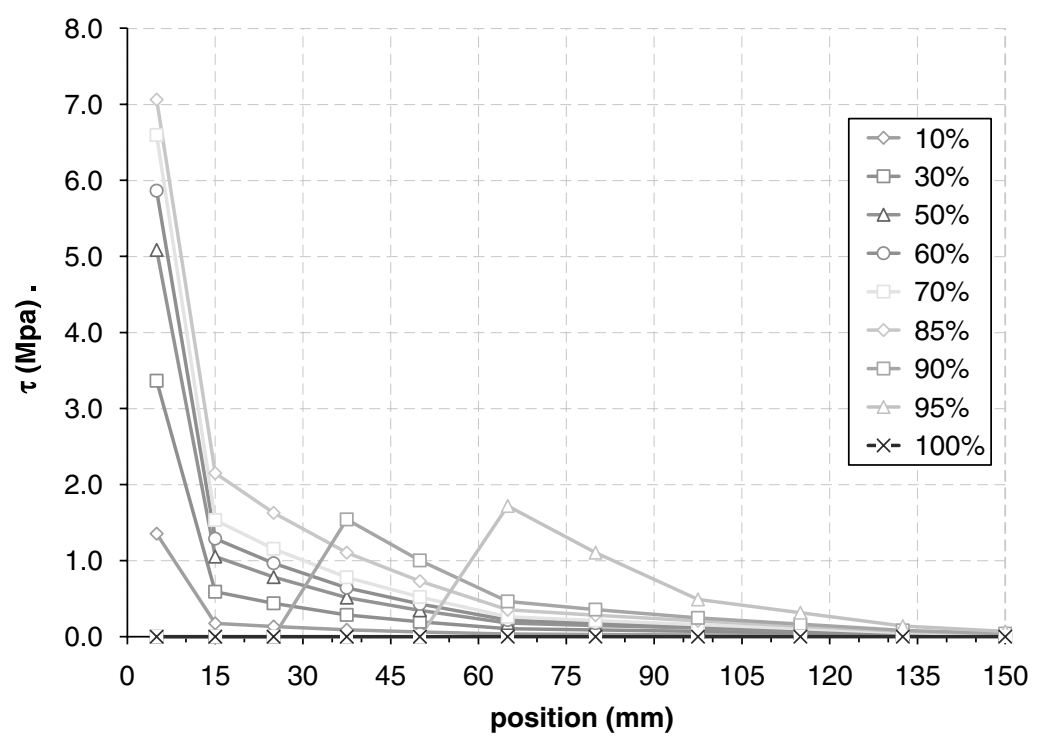

Figure 17: Local shear bond stresses, specimen ST/C4

\section{TEST RESULTS ON BEAMS}

Strengthening with optimised hardwood dowels with a mean diameter of $26 \mathrm{~mm}$ and a length of about $130 \mathrm{~mm}$ was adopted, for traditional reinforcement of existing floor beams with additional planks. The optimised diameter allows combined shear-flexural behaviour, avoiding both pin rupture and damage to plank and beam.

The geometrical dimensions of the basic rectangular beams were $b=115 \mathrm{~mm}$ $h=145 \mathrm{~mm}$, to which a flange of $b=250 \mathrm{~mm} h=50 \mathrm{~mm}$ was added to build the compound beams; the extrados was strengthened by boardings $3 \mathrm{~cm}$ thick.

The physical and mechanical characteristics of the wood used in the experimental samples are given in Table 5. The spruce timber employed for the rectangular sections of the compound beams and reinforcing planks had a basic bending elastic modulus of $10,000 \mathrm{MPa}$ (according to UNI-EN 480, 1997) and a shear modulus of $721 \mathrm{MPa}$. The rectangular beams used later for FRP strengthening had high relative humidity (16-22 per cent), and reduced mechanical properties by up to 7,000 MPa for the bending elastic modulus. It is worth noting that conventional values for the elastic modulus of spruce timber are around 11,000 MPa, as reported by Giordano (1999). In particular, rectangular beams tested in original and FRP reinforced conditions revealed 16 per cent of relative humidity content, whereas for T-beams strengthened with FRP this parameter rose to 22 per cent.

Three rectangular-section beams were tested under flexure in original and strengthened conditions, by gluing CFRP sheets covering the base at the intrados for $100 \mathrm{~mm}$ (for CFRP properties, see Table 2). The same strengthening was applied to three compound sections preliminarily strengthened as described above.

Figure 18 shows the ultimate behaviour of plain beams, both rectangular and compound sections, and Figure 19 compares the reinforced samples. Average behaviour is also compared in Figure 20.

For rectangular beams, an average ultimate load of $12.54 \mathrm{kN}$ and an ultimate deflection of $58.75 \mathrm{~mm}$ were detected. Bending behaviour was slightly nonlinear (Figure 20); in 
particular, the beams collapsed at midspan, with a crack following the direction of the fibres (Figure 18a).

Plain compound beams preliminarily strengthened on the upper side were loaded to about $37 \mathrm{kN}$, and two of the three samples were loaded until failure to measure maximum strength. Fairly elastic behaviour was observed during the first loading cycle (UNI-EN $380,1994)$. In the second cycle, failure occurred within the field of large displacements, at an average load of $43.90 \mathrm{kN}$ and an average displacement of $117 \mathrm{~mm}$. In particular, the beam collapsed at midspan and a crack, following the direction of the fibres, involved its whole width (Figure 18b). The chosen fasteners, of diameter $26 \mathrm{~mm}$, showed good behaviour. Only at the maximum load did they reveal small vertical displacements and slight splitting of the holes. The overall flexural behaviour of the tested specimens is shown in Figure 20.

Table 5: Properties of wood used in samples

\begin{tabular}{llllll}
\hline Wood & Use & $\begin{array}{l}\text { Volume mass } \\
\left(\mathrm{kg} / \mathrm{m}^{3}\right)\end{array}$ & $\begin{array}{l}\text { Compressive strength } \\
(\mathrm{MPa})\end{array}$ & $\begin{array}{l}\text { Flexural strength } \\
(\mathrm{MPa})\end{array}$ & $\begin{array}{l}\text { Shear strength } \\
(\mathrm{MPa})\end{array}$ \\
\hline Spruce & $\begin{array}{l}\text { Rectangular beams, } \\
\text { planks, and boarding } \\
\text { Dowels }\end{array}$ & 455 & $44-45$ & 66 & - \\
Beech & 729 & $58-63$ & 121 & 19 \\
\hline
\end{tabular}
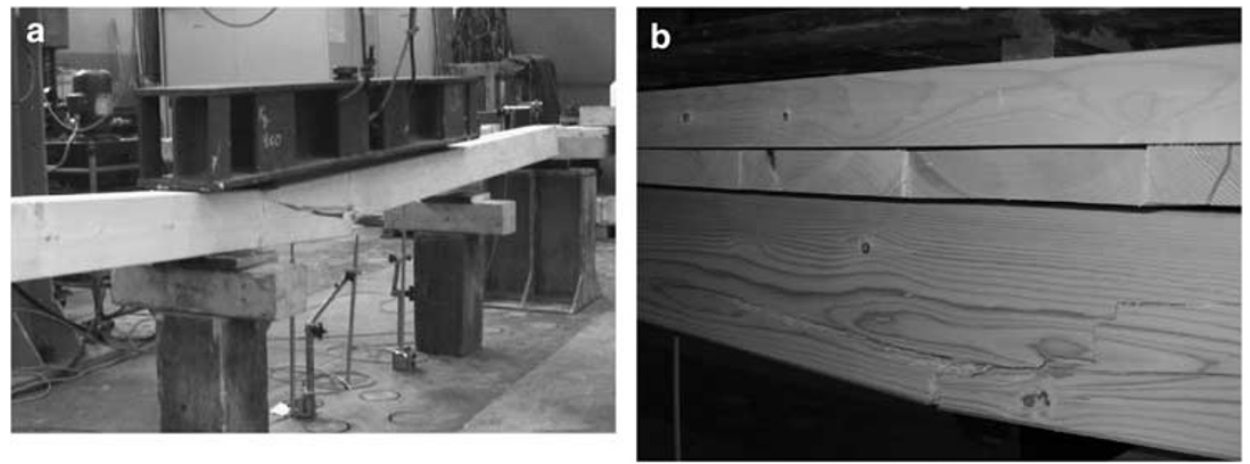

Figure 18: Bending failure in original samples: (a) simple rectangular-section timber beam; (b) compound timber beam
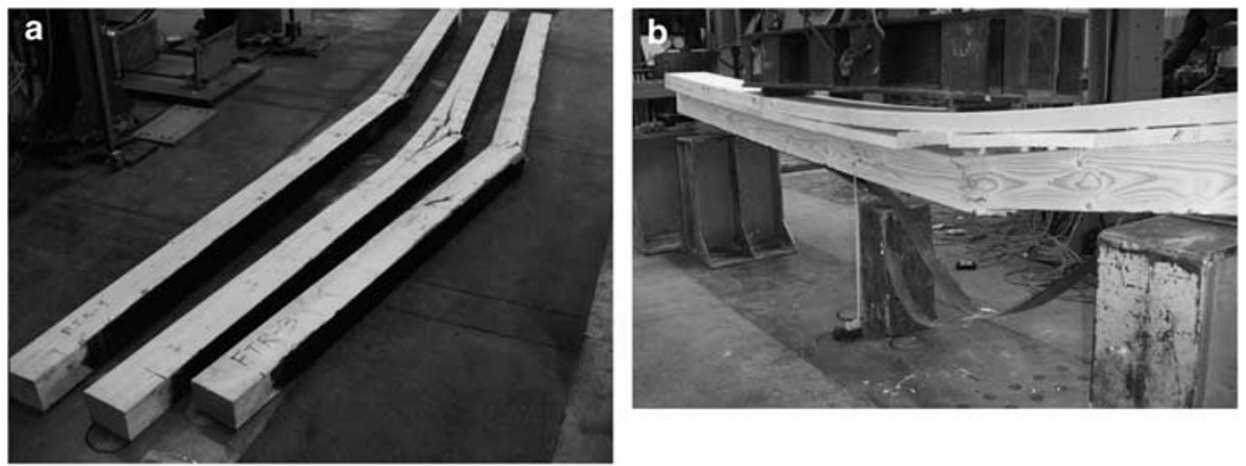

Figure 19: Bending failure in beams strengthened with CFRP sheet: (a) simple timber beam, cracking of timber and an FRP; (b) compound timber beam, detachment of fibres 


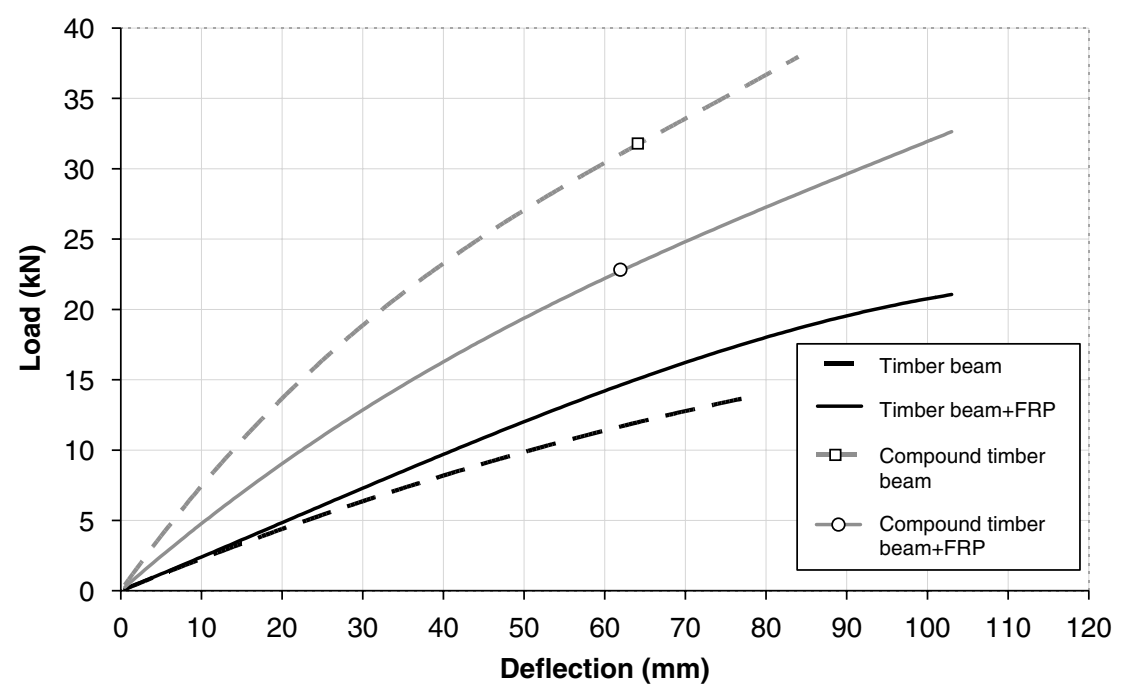

Figure 20: Comparison among flexural behaviour of tested beams (curves represent average data of three tests in each condition; acquisition of displacement was interrupted before collapse to preserve transducer integrity)

Tests on rectangular-section beams strengthened with FRP sheets confirmed the improved bending behaviour described by other researchers (eg, Gentile et al., 2002; Borri et al., 2004). The average ultimate load was $25.11 \mathrm{kN}$, with a deflection of $129 \mathrm{~mm}$. These increases were, respectively, 100 and 122 per cent of those of plain beams. Failure was characterised by abrupt rupture of the CFRP and fibres in the tensile zone (Figure 19a).

Compound timber beams strengthened by CFRP sheets on the underside showed an ultimate load of $32.91 \mathrm{MPa}$ and a corresponding deflection of $110 \mathrm{~mm}$. These values were higher than those of simple beams strengthened by CFRP sheets, but smaller than those of compound timber beams in plain conditions (see Figure 20). Failure was characterised by sudden peeling of the CFRP sheets.

These results indicate not only that the combined technique applied at the upper surface increases strengthening level, but also that the humidity content in the wood before applying an FRP should be carefully checked, as it may influence the overall efficiency of the technique.

Confirmation of this was provided by direct comparison of bending stiffness $(E J)$ in the various test conditions and the theoretical values were computed according to Eurocode 5 (2003) (Figure 21). As expected, for rectangular beams this parameter decreased, due to the progressive plasticisation of the wood in the compression part of the section.

For compound sections strengthened only at the upper side, comparison of experimental results and theoretical bending stiffness, and assuming $K_{s e r}=K_{s e r, \varnothing 26}$, revealed good agreement at a load corresponding to the serviceability state (applied load lower than or equal to $15 \mathrm{kN}$ ).

In simple rectangular-section beams strengthened with an FRP, bending stiffness, computed by homogenisation of the cross-section (Figure 4), showed a trend almost constantly close to the corresponding theoretical value up to a load of $15 \mathrm{kN}$, after which it decreased, due to progressive plasticisation of the wood in the compressed zone. This behaviour was mainly responsible for the reduced deflection in simple beams strengthened by an FRP. 


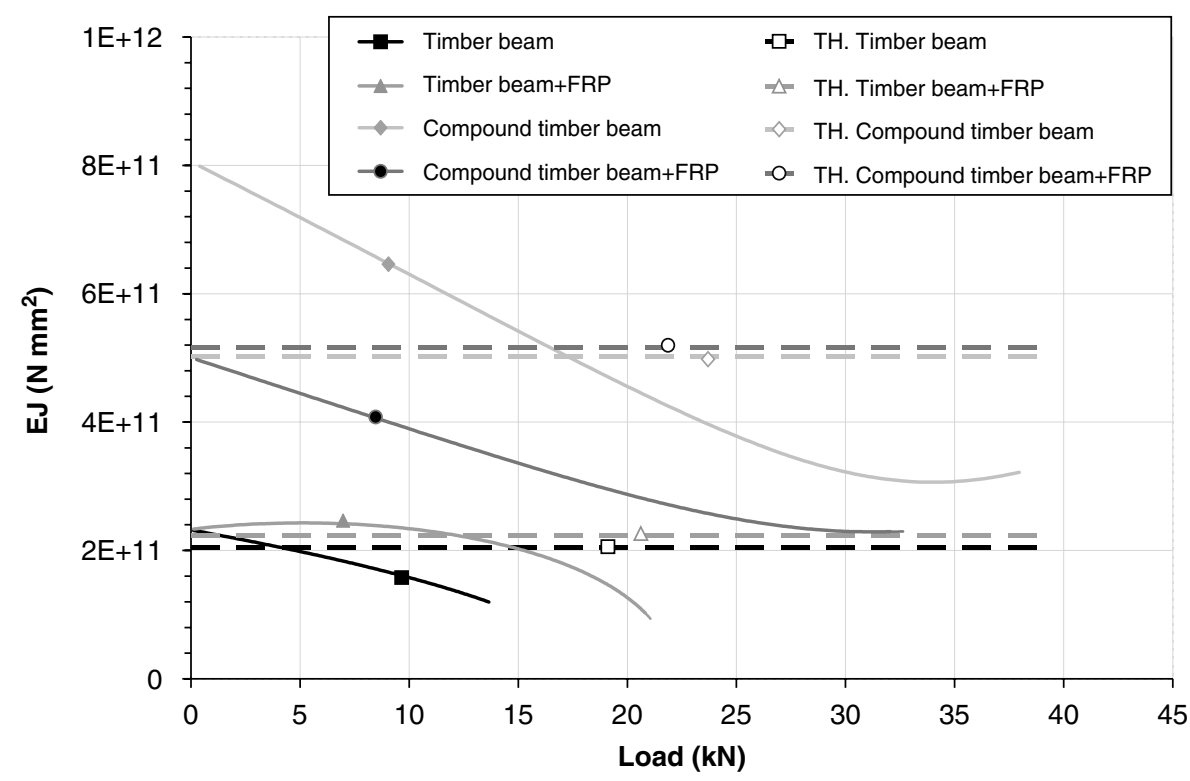

Figure 2 I: Comparison between experimental and theoretical average bending stiffness values

Lastly, the poorer performance of compound beams strengthened additionally at the underside with CFRP may be attributed to their high relative humidity, which does not allow even the initial stiffness of unreinforced compound beams to be reached. The theoretical value of bending stiffness, computed according to Eurocode 5 (2003) using homogenised main beam as in Figure 4, was higher than the experimentally determined value.

\section{CONCLUSIONS}

Flexural strengthening of timber floors may be efficiently improved by the use of compatible techniques, applied by overlapping planks at the upper surface, and connecting them to the main rectangular beams with hardwood fasteners. This technique has been sufficiently validated by experimental campaigns carried out at the University of Padova in the last decade, and it has also been proposed and applied in some case studies.

The application of FRP sheets at the underside of the floor is a promising method of strengthening main beams in order to carry tensile stresses due to bending. Proper preparation of the substrate at the interface and control of the humidity content in wood are, however, particularly important in influencing final mechanical behaviour.

Comparison of results in plain rectangular sections and compound beams strengthened at the upper surface with the 'dry' technique revealed that their ultimate capacity was 3.5 times higher in the strengthened configuration. This advantage fell to about 2.0 times when simple beams were reinforced at the underside with CFRP but was still positive, regardless of the high relative humidity (around 16 per cent). The concurrent presence of upper and lower techniques did not yield the same advantages as with the single application of a mechanically jointed flange, probably due to the high humidity ( 22 per cent) in the beams, even when reinforced at the underside with an FRP, in comparison with the first experimental work (12 per cent). An increase of about 30 per cent was, however, measured in fully strengthened beams in comparison with rectangular 
beams reinforced at the underside with an FRP, thus evidencing the superiority of the 'dry' connection technique on final beam behaviour (relative humidity changes from 16 to 22 per cent from rectangular to T-sections, both in intrados-strengthened conditions).

Control of humidity is confirmed to be very important: it influences the bending elastic modulus of the wood (average of 30 per cent reduction), ultimate strength in bending conditions (36 per cent on compound beams), and bending stiffness (32 per cent reduction in serviceability state).

\section{Acknowledgements}

We thank the company F.lli Bozza Legnami of Busa di Vigonza (Padova) and Eng. D. Francescato for supplying the wood and specimens used for this experimental research, and Degussa MAC of Treviso for FRP materials. We are also grateful to the technical staff of the Laboratory for Structural Materials Testing, Department of Structural and Transportation Engineering, University of Padova; students M. Pomarè and M. Facco (for their contribution in the experimental phases); and Eng. M. Della Benetta (for final processing of results).

\section{References}

Aiello, M.A. and Sciolti, S.M. (2005) 'Bond analysis of masonry structures strengthened with CFRP sheets', Construction and Building Materials, 20(1-2), 90-100.

ASTM C 1583-04 (2004) 'Standard test method for tensile strength of concrete surfaces and the bond strength or tensile strength of concrete repair and overlay materials by direct tension (pull-off method)', American Society for Testing and Materials (ASTM), 5pp.

Borri, A., Corradi, M. and Grazini, A. (2004) 'A method for flexural reinforcement of old wood beams with CFRP materials', Journal of Composites Part B: Engineering, 36(2), 143-153.

CNR-DT200 (2004) 'Guide for the design and construction of externally bonded FRP systems for strengthening existing structures, materials, RC and PC structures, masonry structures', Italian National Research Council (CNR), $154 \mathrm{pp}$.

CNR-DT201 (2005) 'Studi preliminari finalizzati alla redazione di Istruzioni relative a Interventi di Consolidamento Statico di Strutture Lignee mediante 1'utilizzo di Compositi Fibrorinforzati', Italian National Research Council (CNR), 60pp. (in Italian).

Cruz, P., Dias, S. and Branco, J. (2004) 'Availação da aderência da ligação colada madeira-CFRP', Cimad'04 I' Congresso Ibérico, A madeira na construção, Universidade do Minho, Guimarães, Portugal, 25-26 Março 2004, pp. 469-478 (in Portuguese).

Eurocode 5 (2003) 'Final Draft prEN 1995-1-1. Design of timber structures — Part 1-1: General — Common rules and rules for buildings', European Committee for Standardization (CEN), 123pp.

Gentile, C., Svecova, D. and Rizkalla, S.H. (2002) 'Timber beams strengthened with GFRP bars: Development and applications', Journal of Composites for Construction, 6(1), 11-20.

Giordano, G. (1999) Tecnica delle costruzioni in legno, Hoepli, Milan, Italy, 850pp. (in Italian).

Modena, C. (1997) 'Criteria for cautious repair of historic building. A valuation and strengthening of existing masonry structures', in Binda, L. and Modena, C. (eds) Evaluation and Strengthening of Existing Masonry Structures, Proceedings of Joint International Workshop proposed by Rilem TC127/MS-CIB W23, Padova, Rilem.

Modena, C., Tempesta, F. and Tempesta, P. (1997) 'Una tecnica a secco basata sull'uso del legno per l'adeguamento statico di solai in legno', L'edilizia, 11(11/12), 23-32 (in Italian).

Modena, C., Tempesta, F. and Tempesta, P. (1998) 'Il recupero a secco di impalcati in legno', L'Edilizia, 12(3/4), 38-45 (in Italian).

Modena, C., Valluzzi, M.R., Garbin, E. and da Porto, F. (2004) 'A strengthening technique for timber floors using traditional materials', Fourth International Seminar on Structural Analysis of Historical Constructions, Padova, Italy, 10-13 November 2004, Vol. 2, pp. 911-921.

Möhler, K. (1956) Über das Tragverhalten von Biegeträgem und Druckstäben mit zusammengesetztem Querschnitt und nachgiebigen Verbindungsmitteln, Karlsruhe, Germany (in German). 
Parisi, M.A. and Piazza, M. (2003) 'Rehabilitation of timber structures by new materials and fasteners', 10th International Conference and Exhibition: Structural Faults+Repair 2003 London, UK, 1-3 July 2003, 15pp (on CD-ROM).

Piazza, M., Tomasi, R. and Modena, R. (2005) Strutture in legno:materiale, calcolo e progetto secondo le nuove normative europee, Hoepli, Milan, Italy, 734pp. (in Italian).

Tampone, G. (1996) Il restauro delle strutture di legno, Hoepli, Milan, Italy, 401pp. (in Italian).

UNI 9091 (1987) 'Wood — Determination of moisture content — Electrical method', Italian Board for Standardization (UNI), Milan, Italy, 4pp. (Italian translation of technical regulation ISO 4470-81).

UNI-EN 26891 (1991) 'Timber structures — Joints made with mechanical fasteners - General principles for the determination of strength and deformation characteristics', Italian Board for Standardization (UNI), Milan, Italy, 8pp. (Italian translation of technical regulation EN 26891-1991).

UNI-EN 380 (1994) 'Timber methods — General principles for static load testing', Italian Board for Standardization (UNI), Milan, Italy, 9pp. (Italian translation of technical regulation EN 380-1993).

UNI-EN 480 (1997) 'Timber structures — Structural timber and glued laminated timber — Determination of some physical and mechanical properties', Italian Board for Standardization (UNI), Milan, Italy, 20 pp. (Italian translation of technical regulation EN 480-1995). 